\title{
Bazı Tahıl Ürünlerinin Protein Kalite İndeksinin Protein Sindirilebilirliği - Düzeltilmiş Amino Asit Skoru (PDCAAS) Metodu ile Belirlenmesi
}

\author{
Sabiha Zeynep Aydenk Köseoğlu* \\ ${ }^{1}$ Istanbul Zaim Üniversitesi, Sağlık Bilimleri Fakültesi, Beslenme ve Diyetetik Bölümü, Halkalı Cad. No:2 Halkalı Küçükçekmece 34303 İstanbul Türkiye, \\ ORCID: 0000-0001-7936-8462
}

(İlk Geliş Tarihi 1 Ekim 2019 ve Kabul Tarihi 27 Ekim 2019)

(DOI: 10.31590/ejosat.633638)

\begin{abstract}
ATIF/REFERENCE: Aydenk Köseoğlu, S. Z. (2019). Bazı Tahıl Ürünlerinin Protein Kalite İndeksinin Protein Sindirilebilirliği Düzeltilmiş Amino Asit Skoru (PDCAAS) Metodu ile Belirlenmesi. Avrupa Bilim ve Teknoloji Dergisi, (17), 477-482.

$\ddot{\mathbf{O z}}$

Amaç: Bu çalışmanın amacı ülkemizde yaygın olarak tüketilen ve bitkisel protein kaynaklarından olan bazı tahıl, kuru baklagiller ve yağlı tohumluların protein kalitesinin protein sindirilebilirliği - düzeltilmiş amino asit skoru (PDCAAS) yöntemine göre teorik olarak hesaplanması ve elde edilen sonuçlara göre sağlıklı beslenme yönünden öneminin tartışılmasıdır. Materyal ve Metod: Protein kalitesini belirlemede kullanılan PDCAAS yöntemi FAO ve WHO tarafindan 1991 yllında bir besinin protein kalitesini değerlendirmede kullanılan bir ölçüdür. Bir besindeki proteinin PDCAAS'ını belirlemede esansiyel aminoasitlerin toplam protein oranının (amino asit skoru) protein sindirilebilirlik oranlarının ile çarpılarak hesaplanması esasına dayanır. Çalışma kapsamına tahıl ürünleri, kuru baklagiller ve bazı yağlı tohumlular alınmıştır. Ürünler sıra ile buğday ekmeklik, buğday unu, çavdar, yulaf, beyaz, mısır, sert kuru, pirinç, arpa, buğday ruşeymi, yulaf kepeği, pilavlık bulgur, nohut, barbunya, kırmızı mercimek, findık, antep fistığı ve ceviz'dir. Bulgular: Tahıl ürünlerinin PDCAAS skorları 63 ile 95 arasında, kuru baklagillerde 68 ile 100 arasında ve yağlı tohumlarda ise 47 ile 80 arasındadır. PDCAAS skoru 100 üzeri olan gıdaların skorları 100 ya da 1 olarak düzeltilmiştir. PDCAAS belirlemede sınırlayıcı amino asitlerin daha çok, lizin, metiyonin+sistein, treonin, triptofan ve valinin olduğu görülmektedir. Sonuç: Bu çalışmanın da sonucu olarak protein yönünden zengin diyetler hazırlamada bu skorların göz önüne alınması optimal sağlıklı beslenme açısından büyük önem taşımakta olup beslenme profesyonelleri tarafindan bu durum dikkate alınmalıdır.
\end{abstract}

Anahtar Kelimeler: Bitkisel protein, protein kalitesi, sindirilebilirlik, PDCAAS

\section{Determination of protein quality index of some cereal products by protein digestibility corrected amino acid score (PDCAAS) method}

\begin{abstract}
Aim: The aim of this study is to determine the protein quality of some cereals, legumes and oilseeds which are widely consumed in our country and which are one of the vegetable protein sources according to protein digestibility - corrected amino acid score (PDCAAS) method and to discuss the importance of healthy nutrition according to the obtained results. Material and method: The PDCAAS method used to determine protein quality is a measure used by FAO and WHO in 1991 to evaluate the protein quality of a food. Determination of the PDCAAS of a protein in a food is based on the calculation of the total protein ratio (amino acid score) of the essential amino acids by multiplying the protein digestibility ratios. Cereal products, legumes and some oilseeds were included in the study. Products include bread wheat, wheat flour, rye, oats (white), corn (hard dry), rice, barley (two rows), wheat germ, oat bran, rice bulghur, chickpeas, red beans, red lentils, hazel nut, pistachios and walnut. Results: PDCAAS scores of cereal products were between 63 and 95 , between 68 and 100 in dry legumes and between 47 and 80 in oilseeds. Foods with a PDCAAS score above 100 were corrected to 100 or 1. It is seen that the limiting amino acids in PDCAAS determination are mostly lysine, methionine + cysteine, threonine tryptophan and valine. Conclusion: As a result of this study, considering protein scores in preparing protein rich diets is of great importance for optimal healthy nutrition and should be taken into consideration by nutrition professionals.
\end{abstract}

\footnotetext{
*Sorumlu Yazar: Istanbul Zaim Üniversitesi, Sağlık Bilimleri Fakültesi, Beslenme ve Diyetetik Bölümü, ORCID: 0000-0001-7936-8462 szaydenk@gmail.com
} 
Keywords: Vegetable protein, protein quality, digestibility, PDCAAS

\section{Giriş}

Günlük enerji gereksinimlerimiz temel olarak karbonhidratlar, yağlar ve proteinler yoluyla karşılanmaktadır. Bu makro besin ögelerinin arasında proteinler, enerji gereksinimine katkı oranları diğerlerine göre daha az olmasına rağmen, sağlık açısından çok önemli bir yere sahiptir. [Baysal, 2015]. Proteinler amino asitlerden oluşmaktadır ve yaşam için elzemdir. Proteinler organizmada enzim, hormon, taşıma ve depolama ve reseptör gibi birçok faaliyetlerde bulunur [Collins, 2009]. Proteinler amino asitlerden oluşmaktadır ve yaşam için elzemdir. Proteinler organizmada enzim, hormon, taşıma ve depolama ve reseptör gibi birçok faaliyetlerde bulunur [Collins, 2009]. Günlük enerji kaynağımızın yaklaşık \%10-15 arasını proteinlerden alırız [Köseoğlu, 2017]. Bir besinin protein kalitesini içerinde barındırdığı elzem amino asit miktarı belirler [Collins, 2009; Leser, 2013]. Yeterli protein alımı; kilo kontrolü [Halton, 2004], kemik sağlığı [Darling, 2009; Kerstetter, 2011], kalp sağlı̆̆1 [Clifton, 2009], kan şekeri kontrolü [Promintzer, 2006], kas gelişimi (Bopp, 2008; Loenneke, 2010; Mettler, 2010), büyüme ve gelişme olmak üzere optimal sağlığın korunması ve devamlılığının sağlanmasında vital önem taşımaktadır.

Günlük protein gereksinmesi, büyüme ve gelişme döneminde daha fazla iken yetişkinlerde bu gereksinim kg başına daha düşüktür. Protein gereksiniminin miktar olarak karşılanmasının yanı sıra proteinin içerdiği amino asit kompozisyonu da önem teşkil etmektedir. Besinsel protein tüketiminin fizyolojik etkileri ile ilişkili çalışmaların birçoğu, protein miktarına odaklanmaktadır [FAO/WHO, 1991]. Bunun yanı sıra, protein kalitesinin iştah, enerji metabolizması ve iskelet kası protein sentezi gibi faktörlerin etkilenmesinde de ayrılmaz bir rol oynadığına dair kanıtlar vardır [Alfenas Rde, 2010; Mortensen, 2009; Symons, 2009]. Bir proteinin besin kalitesi, proteinin bir organizmanın azot ve amino asit taleplerini karşılayabilme yeterliliği ile belirlenir [FAO/WHO, 1991].

Tahıl ürünleri hayvansal kaynaklı ürünlere göre karşılaştırıldığında protein kalitesi daha düşüktür. Özellikle 1sıl işlem görmüş tahıl ürünlerinde isolöysin, löysin , treonin, lizin ve valin amino asitlerinde kayıplar olduğu da bilinmektedir. Bu amino asitler arasında lizin amino asidi, proses aşamalarından daha fazla etkilendiğinden bir besinin protein kalitesini önemli derecede etkilemektedir.

Protein kalitesini değerlendirmede en yaygın kabul edilen yöntem, Protein Sindirilebilirliği - Düzeltilmiş Amino Asit Skoru (PDCAAS) 'dur [Schaafsma, 2005]. PDCAAS yöntemi FAO ve WHO tarafindan 1991 yılında bir besinin protein kalitesini değerlendirmede kullanılan bir ölçüdür. PDCAAS yöntemi protein kalitesini esansiyel aminoasitlerin toplam protein oranına göre değerlendirme esasına dayanmaktadır. Sıçanlarla yapılan bir çalışmada, sindirilen ham protein oranının sınırlayıcı amino asit skoru ile çarpımı ile PDCAAS değerine ulaşılmaktadır. Bir besindeki proteinin PDCAAS 'nın 1 olması, protein içerisindeki esansiyel aminoasitlerin organizmanın ihtiyaç duyduğu elzem aminoasitlerin \%100’ünü karşılama potansiyeline sahip olduğunu ifade etmektedir. Besinlerin protein sindirilebilirlik oranlarının düşük veya yüksek olması PDCAAS değerini önemli ölçüde etkilemektedir [FAO/WHO, 1991]. Lizin, sülfürlü amino asitler, treonin, triptofan, valin, isolöysin ve löysin yapılan bazı çalışmalarda PDCAAS değerini hesaplamada sınırlayıcı amino asitler olarak belirlenmiştir [Caire-Juvera, 2013; Pérez-Conesa, 2002].

Bir besinin PDCAAS'ı konusunda yapılan çalışma sayısı çok azdır. Bunun nedeni klinik çalışmaların etik kurul onayı, zaman ve maliyet açısından dezavantaja sahip olmasıdır. Yapılan son çalışmalarda in vitro ve in vivo çalışmalar arasında önemli ölçüde korelasyon saptanmış olup, bir besinin PDCAAS 'sini belirlemede in vitro çalışmalar daha çok tercih edilmektedir [Rozan, 2017].

Bu çalışmanın amacı ülkemizde yaygın olarak tüketilen bazı tahıl ve kuru baklagillerin protein kalitesinin PDCAAS yöntemine göre teorik olarak hesaplanması ve elde edilen sonuçlara göre sağlıklı beslenme yönünden öneminin tartışılmasıdır.

\section{Materyal ve Metot}

Çalışma kapsamına tahıl ürünleri, kuru baklagiller ve bazı yağlı tohumlular alınmıştır. Ürünler sıra ile buğday ekmeklik, buğday unu, çavdar, yulaf, beyaz, mısır, sert kuru, pirinç, arpa, buğday ruşeymi, yulaf kepeği, bulgur pilavlık, nohut, barbunya, kırmızı mercimek fındık, antepfıstığı ve ceviz'dir. Protein ve amino asit değerleri: Çalışmaya dahil edilen tahıl ve kuru baklagillerin protein ve amino asit değerleri Ulusal Gıda Kompozisyon Veri Tabanı (TURKOMP) 'nından alınmıştır. Tahıl ve kuru baklagillerin sindirilebilirlikleri değişkenlik göstermektedir. Bu ürünlere ait ortalama protein sindirebilirlik değerleri ise Abdel-Aal vd. (2002) tarafından ortalama değer $(\% 86,7)$ alınmıştır. FAO/WHO/UNU (2007) tarafından bir besinin amino asit skoru ve protein sindirilebilirliği-düzeltilmiş amino asit skoru (PDCAAS) değerlerini ait hesaplama metodu aşağıda gösterilmiştir. Hesaplamada bilinen en kaliteli protein olan anne sütü proteini esas olarak alınmıştır. PDCAAS hesaplamada, 20 amino asit içinde 11 amino asidin gram protein başına düşen $\mathrm{mg}$ amino asit miktarı ilişkilendirilmiştir. $\mathrm{Bu}$ amino asitler genel olarak elzem amino asitlerdir. Bu hesaplama yönteminde aromatik amino asitlerden fenilalanin ve tirozinin toplamı ve sülfürlü amino asitlerden metionin ve sisteinin toplam değerleri alınmıştır. Tablo 1'de anne sütüne ait gram protein içindeki bu 11 amino asidin referans değerleri verilmiştir [FAO/WHO, 2007]. 


\begin{tabular}{|l|l|}
\hline Amino Asit & $\mathrm{mg} / \mathrm{g}$ toplam protein \\
\hline Histidin & 21 \\
\hline İzo-Lösin & 55 \\
\hline Lösin & 96 \\
\hline Lizin & 69 \\
\hline Metiyonin+Sistein & 33 \\
\hline Fenilalanin+Tirozin & 94 \\
\hline Treonin & 44 \\
\hline Triptofan & 17 \\
\hline Valin & 55 \\
\hline
\end{tabular}

Ref: Dietary protein quality evaluation in human nutrition [FAO/WHO, 1991]

Protein gereksinimi bebeklik döneminde kg başına daha fazla iken, çocukluk ve yetişkinlerde bu gereksinim daha azdır. Bu bilgiye göre FAO/WHO/UNU (2007) belirli yaş guruplarına ait gram protein başına alınacak amino asit (mg) değerleri belirlemiştir. Tablo 2'de görüldüğü gibi yaş arttıkça gram protein içindeki amino asit (mg) miktarı azalmaktadır.

Tablo 2. Yaş gruplarına göre gram protein başına mg cinsinden amino asit değerleri.

\begin{tabular}{|l|l|l|l|l|l|l|l|l|}
\hline Amino Asit (mg/g toplam protein) & Histidin & İzo-Lösin & Lösin & Lizin & $\begin{array}{l}\text { Metiyonin } \\
\text { +Sistein }\end{array}$ & $\begin{array}{l}\text { Fenilalanin } \\
\text { +Tirozin }\end{array}$ & Treonin & Triptofan \\
\hline Yaş & 21 & 55 & 96 & 69 & 33 & 94 & 44 & 17 \\
\hline $0-5$ yaş & 20 & 32 & 66 & 57 & 27 & 52 & 31 & 8,5 \\
\hline $1 \_2$ & 18 & 31 & 63 & 52 & 25 & 46 & 27 & 7 \\
\hline $3 \_10$ & 16 & 30 & 61 & 48 & 23 & 41 & 25 & 6,6 \\
\hline $11 \_14$ & 16 & 30 & 61 & 48 & 23 & 41 & 25 & 6,6 \\
\hline $15 \_18$ & 16 & 30 & 60 & 47 & 23 & 40 & 24 & 6,3 \\
\hline$>18$ & 15 & 30 & 59 & 45 & 22 & 38 & 23 & 6 \\
\hline
\end{tabular}

Ref: Dietary protein quality evaluation in human nutrition [FAO/WHO, 1991]

Amino asit skoru hesaplanması: Amino asit skoru belirlenecek besinde, ilk önce gram protein içindeki amino asit (mg) hesaplanır. Daha sonra hangi yaş grubu için hesaplama yapılacaksa Tablo 2'de belirtilen değerlere bölünür. Elde edilen değerler amino asit skorudur. PDCAAS belirlemede ise en küçük oran alınır. Bu amino aside PDCAAS belirlemede sınırlayıcı amino asit denir. Sınırlayıcı amino asit değeri ile o besindeki protein sindirilebilirdik değeri ile çarpılır ve PDCAAS değeri hesaplanmış olur.

\section{Araştırma Sonuçları ve Tartışma}

Tablo 3'de Ulusal Gida Kompozisyon Veri Tabanı (TURKOMP) tarafindan incelenen besinlerin amino asit kompozisyonu ve protein değerleri verilmiştir. Tablo 4'de ise gram protein başına düşen amino asit miktarları ve Tablo 5'te ise sinırlayıcı amino asitler ve PDCAAS değerleri bulunmaktadır. Ekmeklik buğday ve buğday ununun amino asit değerleri karşılaştırıldığında (Tablo 4) özellikle lizin, treonin ve triptofan'da önemli ölçüde azalma görülmüştür. Ekmeklik buğday ve buğday ununun PDCAAS skorlarını karşılaştırdığımızda ise buğday ekmekliğin 95 iken buğday ununun $65^{\prime}$ tir. Ekmeklik buğdayda, PDCAAS skorunu belirlemede sınırlayıcı amino asit treonin amino asidinin, buğday ununda ise lizin amino asidinin etkili olduğu görülmektedir. Çavdar ve yulafin amino asit değerlerininim ( $\mathrm{mg} / \mathrm{g}$ protein) birbirine yakın olduğu ve PDCAAS belirlemede her iki örnekte de sınırlayıcı amino asit olarak treoninin etkili olduğu görülmüştür. Bunun yanında çavdarın PDCAAS' sının 75 ve yulafın ise 74 olduğu ve birbirine yakın olduğu saptanmıştır. Yulaf'ta PDCAAS belirlemede treoinin sınırlayıcı amino asit iken yulaf kepeğinde ise valin amino asidi olduğu ve PDCAAS skorunun da 73 olduğu görülmüştür. Mısır ve pirinç örneklerinin amino asit değerleri karşılaştırıldığında mısır'da triptofanın çok düşük olduğu görülmektedir (Tablo 4). PDCAAS belirlemede mısırda iso-lösin amino asidi etkili olurken pirinç örneğinde ise lizinin etkili olduğu saptanmıştır. Her iki örneğin PDCAAS skorlarına bakıldığında ise mısır'ın 82 iken pirincin 68 olduğu hesaplanmıştır. Bulgur ve buğday rüşeyminin PDCAAS değerlerinin buğdayınkinden düşük olduğu görülmektedir. PDCAAS belirlemede buğday rüşeyminde sınırlayıcı amino asit grubu metiyonin+sistein iken bulgurda valin'dir. Her iki örneğin de PDCAAS değerleri buğdaya göre daha düşüktür. Arpa örneğinin PDCAAS'ını belirlemede buğdayda olduğu gibi sınırlayıcı amino asitin treonin olduğu saptanmıştır. Fakat arpa'nın PDCAAS skorunun buğdaya göre daha düşük olduğu da görülmüştür. Kuru baklagillerden nohut örneğinin PDCAAS'nı belirlemede sınırlayıcı amino asit valin iken, kırmızı mercimek örneğinde triptofan olduğu saptanmıştır. Buna rağmen her iki örneğin de amino asit skorları 1 ve PDCAAS değerlerinin 1'in üzerinde olduğu görülmektedir. Fakat barbunya örneğinde sinırlayıcı amino asidin löysin olduğu ve PDCAAS skorunun da (68) diğer kuru e-ISSN: 2148-2683 
baklagillere göre çok daha düşük olduğu saptanmıştır. Antep fistığı, ceviz ve findık örneklerinde dallı-zincirli amino asitler olan valin, löysin ve iso-löysin amino asit değerlerinin diğer gıda gruplarına göre düşük olduğu görülmektedir. Dolayısıyla protein kalitesini önemli ölçüde etkilemektedir.

Tablo 3. Amino asit skoru hesaplamada kullanılan örneklerin protein ( $g / 100 g)$ ve amino asit değerleri (mg/100g).

\begin{tabular}{|l|c|c|c|c|c|c|c|c|c|c|}
\hline & $\begin{array}{c}\text { Protein } \\
\mathrm{g} / 100 \mathrm{~g}\end{array}$ & $\begin{array}{c}\mathrm{HIS} \\
\mathrm{mg} / \mathrm{g}\end{array}$ & $\begin{array}{c}\text { ILE } \\
\mathrm{mg} / \mathrm{g}\end{array}$ & $\begin{array}{c}\text { LEU } \\
\mathrm{mg} / \mathrm{g}\end{array}$ & $\begin{array}{c}\text { LYS } \\
\mathrm{mg} / \mathrm{g}\end{array}$ & $\begin{array}{c}\text { MET+ CYS } \\
\mathrm{mg} / \mathrm{g}\end{array}$ & $\begin{array}{c}\text { PHE+TYR } \\
\mathrm{mg} / \mathrm{g}\end{array}$ & $\begin{array}{c}\text { THR } \\
\mathrm{mg} / \mathrm{g}\end{array}$ & $\begin{array}{c}\text { TRP } \\
\mathrm{mg} / \mathrm{g}\end{array}$ & $\begin{array}{c}\text { VAL } \\
\mathrm{mg} / \mathrm{g}\end{array}$ \\
\hline Buğday ekmeklik* & 11,3 & 241 & 415 & 837 & 629 & 277 & 970 & 283 & 184 & 507 \\
\hline UN 550* & 10,66 & 145 & 555 & 972 & 310 & 282 & 1238 & 192 & 131 & 637 \\
\hline Çavdar* & 7,68 & 136 & 222 & 434 & 509 & 192 & 529 & 154 & 139 & 294 \\
\hline Yulaf, Beyaz* & 11,35 & 236 & 406 & 806 & 610 & 254 & 989 & 223 & 166 & 545 \\
\hline Misır, Sert Kuru* & 9,7 & 203 & 277 & 938 & 567 & 231 & 789 & 212 & 74 & 366 \\
\hline Pirinç, Osmancık* & 6,84 & 129 & 185 & 421 & 241 & 190 & 561 & 130 & 160 & 256 \\
\hline Arpa iki sıralı* & 9,75 & 162 & 379 & 733 & 499 & 305 & 890 & 197 & 151 & 474 \\
\hline Buğday Ruşeymi* & 29,64 & 1084 & 888 & 1762 & 2019 & 593 & 1959 & 1450 & 361 & 1312 \\
\hline Yulaf Kepeği* & 12,88 & 148 & 282 & 718 & 486 & 624 & 831 & 229 & 176 & 347 \\
\hline Bulgur Pilavlı** & 12,08 & 744 & 427 & 1015 & 1561 & 479 & 962 & 520 & 146 & 485 \\
\hline Nohut* & 18,56 & 634 & 937 & 1517 & 2438 & 650 & 1803 & 748 & 178 & 1001 \\
\hline Barbunya* & 21,07 & 771 & 755 & 964 & 2728 & 902 & 1384 & 1086 & 181 & 668 \\
\hline Kırmızı Mercimek* & 25,81 & 835 & 1273 & 2001 & 3610 & 734 & 2427 & 949 & 200 & 1305 \\
\hline Fındı* & 14,24 & 282 & 348 & 695 & 671 & 242 & 796 & 251 & 237 & 418 \\
\hline Antep Fıstığ1* & 17,64 & 406 & 492 & 972 & 1486 & 331 & 1120 & 372 & 268 & 634 \\
\hline Ceviz* & 14,57 & 538 & 569 & 967 & 353 & 296 & 1098 & 1083 & 347 & 655 \\
\hline
\end{tabular}

Ref*: www.turkomp.gov.tr

Tablo 4. Amino asit skoru hesaplamada $\mathrm{mg} / \mathrm{g}$ protein değerleri.

\begin{tabular}{|l|c|c|c|c|c|c|c|c|c|}
\hline & HIS & ILE & LEU & LYS & MET+CYS & PHE+TYR & THR & TRP & VAL \\
\hline Referan, Yetişkin $>18$ yaş* & $15^{*}$ & $30^{*}$ & $59^{*}$ & $45^{*}$ & $22^{*}$ & $38^{*}$ & $23^{*}$ & $6^{*}$ & $39^{*}$ \\
\hline Buğday ekmeklik & 21 & 37 & 74 & 56 & 25 & 86 & 25 & 16 & 45 \\
\hline UN 550 & 14 & 52 & 91 & 29 & 26 & 116 & 18 & 12 & 60 \\
\hline Çavdar & 18 & 29 & 57 & 66 & 25 & 69 & 20 & 18 & 38 \\
\hline Yulaf, Beyaz & 21 & 36 & 71 & 54 & 22 & 87 & 20 & 15 & 48 \\
\hline Mısır, Sert Kuru & 21 & 29 & 97 & 58 & 24 & 81 & 22 & 8 & 38 \\
\hline Pirinç, Osmancık & 19 & 27 & 62 & 35 & 28 & 82 & 19 & 23 & 37 \\
\hline Arpa iki sıralı & 17 & 39 & 75 & 51 & 31 & 91 & 20 & 15 & 49 \\
\hline Buğday Ruşeym & 37 & 30 & 59 & 68 & 20 & 66 & 49 & 12 & 44 \\
\hline Yulaf Kepeği & 11 & 22 & 56 & 38 & 48 & 65 & 18 & 14 & 27 \\
\hline Bulgur Pilavlık & 62 & 35 & 84 & 129 & 40 & 80 & 43 & 12 & 40 \\
\hline Nohut & 34 & 50 & 82 & 131 & 35 & 97 & 40 & 10 & 54 \\
\hline Barbunya & 37 & 36 & 46 & 129 & 43 & 66 & 52 & 9 & 32 \\
\hline Kırmızı Mercimek & 32 & 49 & 78 & 140 & 28 & 94 & 37 & 8 & 51 \\
\hline Antep Fıstığı & 23 & 28 & 55 & 84 & 19 & 63 & 21 & 15 & 36 \\
\hline Ceviz & 37 & 39 & 66 & 24 & 20 & 75 & 74 & 24 & 45 \\
\hline Findık & 20 & 24 & 49 & 47 & 17 & 56 & 18 & 17 & 29 \\
\hline
\end{tabular}

Ref*: Dietary protein quality evaluation in human nutrition [FAO/WHO, 1991] 
Antep fıstığının PDCAAS' ını belirlemede sınırlayıcı amino asitin, hem treoinin hem de valin olduğu belirlenmiştir. Findıkta da PDCAAS belirlemede sınırlayıcı amino asit valindir. Cevizde ise sınırlayıcı amino asit lizin'dir. Bu üç yağlı tohum örneğinin PDCAAS' na bakıldığında, Antep fistığının 80, findığın 65 ve cevizin ise 47 olduğu saptanmıştır. Görüldüğü gibi hem findık hem de cevizin PDCAAS değerlerinin genel olarak düşük olduğu görülmektedir.

Tablo 5. Örneklere ait düzeltilmiş amino asit skorları, stnırlayıcı amino asitler ve PDCAAS değerleri.

\begin{tabular}{|c|c|c|c|c|c|c|c|c|c|c|}
\hline Örnek & HIS & ILE & LEU & LYS & MET+CYS & PHE+TYR & THR & TRP & VAL & PDCAAS \\
\hline Buğday ekmeklik & 1,42 & 1,22 & 1,26 & 1,24 & 1,11 & 2,26 & 1,09 & 2,71 & 1,15 & 95 \\
\hline UN 551 & 0,91 & 1,74 & 1,55 & 0,65 & 1,2 & 3,06 & 0,78 & 2,05 & 1,53 & 56 \\
\hline Çavdar & 1,18 & 0,96 & 0,96 & 1,47 & 1,14 & 1,81 & 0,87 & 3,02 & 0,98 & 75 \\
\hline Yulaf & 1,39 & 1,19 & 1,2 & 1,19 & 1,02 & 2,29 & 0,85 & 2,44 & 1,23 & 74 \\
\hline Mısır, Sert Kuru & 1,4 & 0,95 & 1,64 & 1,3 & 1,08 & 2,14 & 0,95 & 1,27 & 0,97 & 82 \\
\hline Pirinç, Osmancık & 1,26 & 0,9 & 1,04 & 0,78 & 1,26 & 2,16 & 0,83 & 3,9 & 0,96 & 68 \\
\hline Arpa iki sıralı & 1,11 & 1,3 & 1,27 & 1,14 & 1,42 & 2,4 & 0,88 & 2,58 & 1,25 & 76 \\
\hline Buğday Ruşeymi & 2,44 & 1 & 1,01 & 1,51 & 0,91 & 1,74 & 2,13 & 2,03 & 1,13 & 79 \\
\hline Yulaf Kepeği & 0,77 & 0,73 & 0,94 & 0,84 & 2,2 & 1,7 & 0,77 & 2,28 & 0,69 & 63 \\
\hline Bulgur Pilavlık & 4,11 & 1,18 & 1,42 & 2,87 & 1,8 & 2,1 & 1,87 & 2,01 & 1,03 & 89 \\
\hline Nohut & 2,28 & 1,68 & 1,39 & 2,92 & 1,59 & 2,56 & 1,75 & 1,6 & 1,38 & 120 \\
\hline Barbunya & 2,44 & 1,19 & 0,78 & 2,88 & 1,95 & 1,73 & 2,24 & 1,43 & 0,81 & 68 \\
\hline Kırmızı Mercimek & 2,16 & 1,64 & 1,31 & 3,11 & 1,29 & 2,47 & 1,6 & 1,29 & 1,3 & 112 \\
\hline Antep Fıstı̆ı̆ & 1,53 & 0,93 & 0,93 & 1,87 & 0,85 & 1,67 & 0,92 & 2,53 & 0,92 & 80 \\
\hline Ceviz & 2,46 & 1,3 & 1,12 & 0,54 & 0,92 & 1,98 & 3,23 & 3,97 & 1,15 & 47 \\
\hline Fındık & 1,32 & 0,81 & 0,83 & 1,05 & 0,77 & 1,47 & 0,77 & 2,77 & 0,75 & 65 \\
\hline
\end{tabular}

Sonuçları genel olarak değerlendirdiğimizde tahıl ürünlerinin PDCAAS skorları 63 ile 95 arasında, kuru baklagillerde 68 ile 100 arasında ve yağlı tohumlarda ise 47 ile 80 arasındadır. PDCAAS skoru 100 üzeri olan gidaların skorları 100 ya da 1 olarak düzeltilmektedir. PDCAAS belirlemede sınırlayıcı amino asitlerin daha çok, lizin, metiyonin+sistein, treonin triptofan ve valinin olduğu görülmektedir.

Pérez-Conesa ve ark (2002) yapmış oldukları çalışmalarda tahıl içeren bebek ek gıdalarında kükürtlü amino asitlerin, lizin ve triptofanın PDCAAS belirlemede sınırlayıcı amino asitler olduğunu bildirmiştir. Abdel-Aal ve ark (2002)'nun yapmış oldukları çalışmada sınırlayıcı amino asidin işlenmiş tahıllardaki lizin olduğunu saptamıştır. Başka bir çalışmada ise tahıl bazlı ürünlerde sınırlayıcı amino asit lizin olup, amino asit skorları 0.15 ila 0.54 arasında değişmiştir (Caire-Juvera, 2013). Aynı çalışmada, baklagil ürünlerinde metiyonin \pm sistein, amino asitleri sımırlayıcı amino asitlerdir ve skorlarının 0,41 ile 0,47 arasında olduğu bulunmuştur. Jullyana ve ark (2012) yapmış oldukları çalışmada findıkların PDCAAS skorlarıın \%57 ile \%90 arasında değiştiği belirtilmiştir. Bizim çalışmamızda da findığın PDCAAS skoru \%65 olduğu görülmektedir.

\section{Sonuç}

$\mathrm{Bu}$ çalışmada tahıl, kuru baklagil ve bazı yağlı tohumluların protein kaliteleri FAO/WHO PDCAAS yöntemine göre değerlendirilmiştir. Bu besinlerin PDCAAS 'ını belirlemede sınırlayıcı amino asitlerin daha çok, lizin, metiyonin+sistein, treonin triptofan ve valinin olduğu görülmektedir. Özellikle işlem görmüş buğday ununun protein kalite indeksinin ögütülmemiş buğdaya göre çok daha düşük olduğu bulunmuştur. Literatürde de belirtildiği gibi proses görmüş ürünlerde lizin miktarında önemli kayıplar olmaktadır. Çalışma kapsamımızda PDCAAS belirlenen buğday ununda lizinin çok düşük olduğu ve PDCAAS belirlemede sınırlayıcı amino asit olduğu görülmektedir. Genel olarak tahıl ürünleri değerlendirildiğinde işlem görmüş un ve yulaf kepeğinin PDCAAS skorunun düşük olduğu tespit edilmiştir. Kuru baklagillerden barbunyanın PDCAAS düşük iken diğerlerinin 1 ya da 100'ün üzerinde olduğu ve iyi bir protein kaynağı olduğunu desteklemektedir. Yağlı tohumlularda ise Antep fistı̆ı̆ının PDCAAS skoru çok iyi iken findık özelliklede cevizin daha düşük olduğu görülmektedir. FAO/WHO'ya göre bir besinin PDCAAS skoru diyetle alınan protein organizmada protein sentezine katılma potansiyelini vermektedir. Dolayısıyla protein yönünden zengin diyetler hazırlanırken bu skorların hesaplanarak protein kaliteleri yönünden değerlendirilmeleri sağlıklı beslenme yönünden önem teşkil etmektedir. Tıbbi beslenme programlarının hazırlanmasında protein miktarlarının yanı sıra besinlerin içerdiği proteinlerin kalitelerinin de göz önüne alınması gerekmektedir. 


\section{Kaynaklar}

[1] Abdel-Aal ES, and Hucl P. [2002]. Amino acid composition and in vitro protein digestibility of selected ancient wheats and their end products. Journal of Food Composition and Analysis, 15(6), 737-747.

[2] Alfenas Rde C, Bressan J, Paiva AC. [2010]. Effects of protein quality on appetite and energy metabolism in normal weight subjects. Arq Bras Endocrinol Metabol, 54(1), pp. 45-51.

doi: 10.1590/S0004-27302010000100008.

[3] Collins N. [2009] Nutrition 411: Understanding the protein digestibility corrected amino acid score (PDCAAS). Ostomy Wound Management, 55(6). https://www.o-wm.com/content/ understanding-protein-digestibility-corrected-amino-acid-score-pdcaas

[4] Baysal A. [2015]. Beslenme. Ankara: Hadipoğlu Yayınları. (ISBN: 978-9757527732)

[5] Bopp MJ, Houston DK, Lenchik L, Easter L, Kritchevsky SB, Nicklas BJ. [2008]. Lean mass loss is associated with low protein intake during dietary-induced weight loss in postmenopausal women. J Am Diet Assoc. 108(7), pp. 1216-1220. doi: 10.1016/j.jada.2008.04.017.

[6] Caire-Juvera G, Vázquez-Ortiz FA, \& Grijalva-Haro MI. [2013]. Amino acid composition, score and in vitroprotein digestibility of foods commonly consumed in Northwest Mexico. Nutr Hosp., 28(2), pp. 365-371. doi: 10.3305/nh.2013.28.2.6219

[7] Clifton PM, Bastiaans K, \& Keogh, JB. [2009]. High protein diets decrease total and abdominal fat and improve CVD risk profile in overweight and obese men and women with elevated triacylglycerol. Nutr Metab Cardiovasc Dis., 19(8), pp. 548-554. doi: 10.1016/j.numecd.2008.10.006

[8] Darling AL, Millward DJ, Torgerson DJ, Hewitt CE, \& Lanham-New SA. [2009]. Dietary protein and bone health: a systematic review and meta-analysis. Am J Clin Nutr., 90(6), pp. 1674-1692. https://doi.org/10.3945/ajcn.2009.27799

[9] FAO/WHO Expert Consultation. [1991]. Report of the Joint FAO/WHO Expert Consultation: Protein Quality Evaluation. FAO Food and Nutrition Paper no.51.

[10] Halton TL, \& Hu FB. [2004]. The effects of high protein diets on thermogenesis, satiety and weight loss: a critical review. J Am Coll Nutr., 23(5), pp. 373-385.

[11] Kerstetter JE, Kenny AM, Insogna KL. [2011]. Dietary protein and skeletal health: a review of recent human research. Curr Opin Lipidol., 22(1), pp. 16-20.

[12] Köseoğlu SZA, \& Tayfur AÇ. [2017]. Adölesan Dönemi Beslenme ve Sorunları. JCP 2017; 15(2): 50-62. https://dergipark.org.tr/tr/download/article-file/333405

[13] Jullyana BF, Daniela CF, Ludmila PC, Jean Carlos RL, Amanda GO S, \& Maria Margareth VN. [2012]. Edible seeds and nuts grown in Brazil as sources of protein for human nutrition. Food and Nutrition Sciences, 3(6), pp. 857-862. doi: 10.4236/fns.2012.36114.

[14] Leser S. [2013]. The 2013 FAO report on dietary protein quality evaluation in human nutrition: Recommendations and implications. Nutrition Bulletin, 38(4), pp. 421-428. https://doi.org/10.1111/nbu.12063

[15] Loenneke JP, Balapur A, Thrower AD, Syler G, Timlin M, Pujol TJ. [2010]. Short report: Relationship between quality protein, lean mass and bone health. Ann Nutr Metab, 57(3-4), pp. 219-220. doi: 10.1159/000321736.

[16] Mettler S, Mitchell N, Tipton KD. [2010]. Increased Protein Intake Reduces Lean Body Mass Loss during Weight Loss in Athletes. Med Sci Sports Exerc., 42(2), pp. 326-337.

[17] Mortensen LS, Hartvigsen ML, Brader LJ, Astrup A, Schrezenmeir J, Holst JJ, Thomsen C, Hermansen K. [2009]. Differential effects of protein quality on postprandial lipemia in response to a fat-rich meal in type 2 diabetes: comparison of whey, casein, gluten, and cod protein. Am J Clin Nutr, 90(1), pp. 41-48. doi: 10.3945/ajcn.2008.27281.

[18] Pérez-Conesa D, Ros G, \& Periago MJ. [2002]. Protein nutritional quality of infant cereals during processing. Journal of Cereal Science, 36(2), pp. 125-133. https://doi.org/10.1006/jcrs.2002.0463.

[19] Promintzer M, Krebs M. [2006]. Effects of dietary protein on glucose homeostasis. Curr Opin Clin Nutr Metab Care, 9(4), pp. 463468.

[20] Schaafsma G. [2005]. The Protein Digestibility-Corrected Amino Acid Score (PDCAAS)-a concept for describing protein quality in foods and food ingredients: a critical review. J AOAC Int., 88(3), pp. 988-994.

[21] Symons TB, Sheffield-Moore M, Wolfe RR, Paddon-Jones D. [2009]. A moderate serving of high-quality protein maximally stimulates skeletal muscle protein synthesis in young and elderly subjects. J Am Diet Assoc, 109(9), pp. 1582-1586. doi: 10.1016/j.jada.2009.06.369.

[22] WHO/FAO/UNU Expert Consultation. [2007]. Protein and amino acid requirements in human nutrition. WHO Technical Report Series, 935, 1-265.

[23] Rozan P, Lamghari R, Linder M, Villaume C, Fanni J, Parmentier M, \& Méjean L. [1997]. In vivo and in vitro digestibility of soybean, lupine, and rapeseed meal proteins after various technological processes. Journal of Agricultural and Food Chemistry, 45(5), pp. 1762-1769. 